UDC 378.091:004.9

\title{
Irina Dobroskok
}

Correspondent Member of the National Academy of Educational Sciences of Ukraine,

Doctor of Pedagogical Sciences, Professor

State Higher Educational Institution «Pereiaslav-Khmelnytskyi Hryhorii Skovoroda State Pedagogical University», Pereiaslav-Khmelnytskyi, Ukraine

ORCID ID 0000-0002-3937-8428

irina.dobroskok@gmail.com

\section{Nataliia Rzhevska}

$\mathrm{PhD}$ of Pedagogical Sciences

State Higher Educational Institution «Pereiaslav-Khmelnytskyi Hryhorii Skovoroda State Pedagogical University», Pereiaslav-Khmelnytskyi, Ukraine

ORCID ID 0000-0001-8695-5964

zolotysya@ukr.net

Hamdi Ayyldız

$\mathrm{PhD}$ in Economics, Turkoglu Vocational School and Project Development and Coordination Center Kahramanmaras Sutcu Imam University, Turkey

ORCID ID 0000-0001-6280-7182

hayyildiz@ksu.edu.tr

\section{Darina Zaimova}

Associate Professor, Vice Rector Project Affairs

Trakia University, Bulgaria

ORCID ID 0000-0001-6971-3701

dzaimova@gmail.com

\section{George Zheliazkov}

$\mathrm{PhD}$, Professor, Head of the Department of Entrepreneurship and Industrial Business

Trakia University, Bulgaria

ORCID ID 0000-0002-2575-6977

george-zh@mbox.digsys.bg

\section{GAME DEVELOPMENT SOFTWARE TOOLS IN HIGHER EDUCATIONAL INSTITUTIONS: EXPERIENCE OF UKRAINE, TURKEY AND BULGARIA}

\begin{abstract}
The article features the analysis of game development software tools in higher educational institutions of Ukraine (Pereiaslav-Khmelnytskyi Hryhorii Skovoroda State Pedagogical University), Turkey (Kahramanmaras Sutcu Imam University) and Bulgaria (Trakia University). The article highlights the results of the research conducted by teachers and students of these universities. In this research, teachers with no previous experience in this field or specialized IT skills created educational games. Free software tools that can be used to create educational games were selected for this research (Construct 3, GameMaker Studio 2, Unity, Godot Engine, Unreal Engine 4). The study included two data arrays: the first was the opinion expressed by teachers who developed educational games, and the second - that of students who tested the final game product. We analyzed free tools for creating educational games according to such criteria: the need for programming language knowledge, availability of support forums and reference materials, ability to export data to multiple platforms and in many formats, add in-app purchases or various components to each object, whether both 2D and 3D games are supported, development speed. In the Ukrainian teachers' opinion, GameMaker Studio 2 was the most effective, while teachers in Turkey and Bulgaria preferred the Unreal Engine 4. According to research results, it is worth noting a high interest of both teachers and students in the creation and use of educational computer games. It should also be noted that these results are relevant only for specific groups under study since they are based on the individual experience of a limited number of students. However, they are significant for shaping ideas about pedagogical strategies and allow teachers to learn new information, try new types of activities and interaction.
\end{abstract}


Keywords: Construct 3; educational game; GameMaker Studio 2; gamification; higher educational institutions; Godot Engine; Unity; Unreal Engine 4.

\section{INTRODUCTION}

Gamification has become one of the most notable technological developments for human engagement [1, p. 11]. The way we teach our university students will directly influence the future of the country's economic growth and power [2, p. 102].

Games perform an important role in psychological, social, and intellectual development and could be defined as a voluntary activity that is intrinsically motivating, involves some level of activity (often physical) and may possess make-believe qualities [3, p. 207]. With the help of games, we can become those who we will never be in real life, we can deal with problems that we may never actually encounter, or we can go back and relive something over and over again and even pause our life. Moreover, games can help visualize dreams, gain experience, improve skills and so on. They have already penetrated many areas of our life.

Video games can "teach higher-order skills, such as strategic thinking, interpretative analysis, problem-solving, plan formulation and execution, and adaptation to rapid change" [4].

Games are not restricted to the entertainment sector. The business sector has long used games and simulations to train staff in developing fiscal, economic and trading skills. The military sector uses simulation-based games (partially due to advances in graphic and A.I. realism) in combat training, while the health/medical sector is increasingly using VR techniques and technologies similar to those used in games. Aircraft pilots and drivers often use simulations in the early stages of training and equipment learning [5, p.2].

Despite a rocky beginning, game programming is now gaining acceptance in academia, resulting in the proliferation of new classes and programs both nationwide and internationally; they have even made their way into a professionally recommended curriculum in game studies [6, p. 511].

Computer games are a modern, dynamic tool that focuses on performance and professional atmosphere during educational activities in educational institutions.

The term "gamification" means the use of game-based methods in student training. It is also defined as the use of videogame elements outside the context of games [7, p.871].

The use of educational games as learning tools is a promising approach due to their abilities to teach and reinforce not only knowledge but also important skills such as problemsolving, collaboration, and communication. Games have a remarkable motivational power; they utilize multiple mechanisms encouraging people to engage with them, often without any reward, just for the joy of playing and the possibility of winning [8, p. 77].

Successful video games are more than just software. The purpose of a game is to compel a user. The chances of a potentially "fun" game with a fascinating storyline and graphics or engaging interface to become popular depend on its software [9].

Gamification can inspire students to learn, as it allows them to solve professional problems in a fun way. Thus, interest in the academic discipline increases, which helps to form the responsibility for the decisions made. Students use their creative skills to survive in the game, which then leads to high grades in the course grade book causing satisfaction with their course choice and the academic program overall [10, p. 131].

Problem statement. With each new software version release come new improvements of usability as well as new formats for output, which require research and testing to seamlessly integrate student's 2D and 3D assets into interfaces used in the game programming course. Rules, interaction system prototypes, creation of game characters, scenes, and animation are all necessary parts of an interactive narrative. 
Original tools for digital games are used to create games from scratch, easily integrate content and game mechanics; they can help in the game production chain in a multitude of ways [11, p. 536].

Game engines, programs, templates for educational games are all relevant topics for leading programming conferences (Proceedings of the IEEE Computer Society Conference on Computer Vision and Pattern Recognition, International Conference on Architectural Support for Programming Languages and Operating Systems - ASPLOS, Proceedings of the Annual ACM Symposium on Theory of Computing, Conference on Human Factors in Computing Systems - Proceedings, Proceedings of the ACM SIGPLAN Symposium on Principles and Practice of Parallel Programming, PPOPP, etc.). From month to month, programmers are working on the creation of innovative game spaces for developing, improving and updating educational game architecture and content. However, an amateur in the field of programming is not always able to create even the simplest game.

A. Rapp et.al. argue that academic research on gamification has been slow in finding ways to improve the techniques to be used for gamified application design [12, p. 1].

Teachers often do not believe in themselves and may even not allow the thought of creating a computer game. Of course, this does not mean game development is easy. But thanks to free game development software tools, a game that once might have taken a year to build can now be made in months or days - sometimes even without any code.

Therefore, it is so important for future teachers of the humanities to review our research and take into account its findings.

When it comes to conceptualizations of gamification, the development could be categorized into two broad categories: gamification objects and gamification mechanics [13, p. 1013].

Gamification objects refer to visual or non-visual digital objects that form building blocks of gamification systems. Examples of gamification objects include graphics, audio clips, avatars, virtual items, artificial characters, storylines, badges and leader boards. Gamification mechanics is a higher level of design that is built based on game artefacts, play patterns and dynamics, such as a level or point-based system, quests, competition, and collaboration, in-game economy and social networking systems [14].

Objects and mechanisms play a significant role in creating an educational game. Therefore, tools for their development should be as accessible to educational game creators as possible and feature high quality for students.

Analysis of recent studies and publications. According to Elsevier, the number of research articles that appear for the query "gamification in higher education", grows every year. In 2011, there were three of them, in 2012 - 5, $2013-10,2014-41,2015-89,2016-$ 131, 2017 - 137, $2018-172,2019-269$. This speaks of increasing attention to gamification, expansion of its application in higher education, and confirms its effectiveness in working with university students.

Researchers have been actively studying all aspects of gamification ranging from participant motivation (I. Glover [15]), empirical studies (J. Hamari, J. Koivisto, H. Sarsa [16]) to specific industry aspects of using a gamified educational environment (G. Barata, S. Gama, J. Jorge, D. Gonçalves [17], B. Leong [18]).

Especially noteworthy are studies by M. Sillaots, who presented a course developed using computer games [19], and S. Smith-Robbins, who offers specific ways to improve gamification technologies and provides practical recommendations for teachers engaged in the development of gamification environment [20, p. 59]. B. Kim, H. Park, Y. Baek research metacognitive strategies within the gamification process [21, p. 802]. Authors suggest several metacognitive strategies depending on the objectives set. The study of metacognitive strategies in gamification is an important aspect in shaping certain competencies as knowledge points. This same 
viewpoint is shared by a group of researchers A. Domínguez et al, who see a gamification mechanism as a universal strategy in any field of knowledge [22, p. 383].

D. Codish, G. Ravid study psychological peculiarities of the gamified environment [23, p.38]. In their research, they suggest developing two strategies: for introverts and extraverts. This division is important, given the level of psychological readiness for computer games.

P. Denny studies one of the most important gamification aspects - motivational [24, p.6]. The question "How does gamification influence the level of student exhaustion in the educational process?" is among major issues in his research. Because students' motivation to participate is one of the benefits of the virtual environment and gamification implementation, the issue under research is important for the scientific society.

E. Bradley Wiggins focuses on the use of games and/or modelling, as well as on the review of gamification strategies by teachers of communication courses at state universities in Arkansas, USA [25, p. 19].

M. Laskowski and M. Badurowicz research practical aspects of implementing gamification into the educational process. Thus, researchers emphasize such benefits as attendance, motivation to further education within the gamified educational environment, enhancing teacher qualifications, etc. [26].

S. Šćepanović, D. Žarić, T. Matijević analyze research dedicated to gamification. The authors agreed that all of the above researchers gamified certain practical tasks and may argue that such gamified activities can help develop practical competencies, but there is still no positive proof on whether gamification can improve mastering the theoretical material [27].

Ukrainian researchers are also actively using educational games.

A. Y. Yurzhenko, S. A. Voloshynov, H. V. Popova develop controlled and semicontrolled activities, which are developed using learningapps.org templates (The Millionaire game, Crossword, Word grid, Horse race, Pairing game, and others) [28].

Gamification was implemented and tested in the framework of the Computer Science course at Odesa Polytechnic University and is now being introduced into the educational process at the Department of Nuclear Power Plants. This approach consists in each student creating his or her own computer game where the student simulates the offender's movement around the controlled territory of the facility, ensures their detection and detention [29, p.248].

The fact that Marharyta Kaliuzhna, the Ukrainian English language teacher, won the prize in the "Gamification" category at the International Microsoft E2-Educator Exchange contest held in Budapest, may be considered an example of successful application of game technologies in the educational process. The project she submitted to the contest focused on the introduction of the innovative approach to organizing a lesson based on game technologies. "Our task was to identify and solve one of the relevant issues that teachers face," Marharyta Kaliuzhna says. "The first minutes of the lesson must grab students' attention and inspire them to study. Therefore, we have developed First Five Minutes - a game concept creating an atmosphere of competition and urging students to learn." In addition, a GameHub international project is being implemented nowadays, which lies in the cooperation between universities and Ukrainian game industry companies. It is aimed at creating a GameHub infrastructure at Ukrainian universities, which will enable involving those interested in this area in learning, improvement of skills and competencies required to work in the game industry [30].

N. M. Rybka describes his own practical experience in implementing a distancelearning "Philosophy" course at Odesa National Polytechnic University, which offers students to test such game forms as Game - Anagram - guess a word, Game - Race after the leader, Game - Book of questions, Game - Cryptex, Game - Crossword, Game - Hidden picture, Game - My game - Millionaire, Game - Sudoku [31]. 
Oksana A. Zhernovnykova, Liudmyla Y. Peretiaha, Anna V. Kovtun, Marina V. Korduban, Oleksii O. Nalyvaiko, and Nataliia A. Nalyvaiko are testing such mobile apps as DuoLingo, Ribbon Hero, ClassDojo, The World Peace Game, Coursera, GoalBook, Mr Pai's Class, Brainscape, and Socrative in the educational process and conclude that these apps contribute to the digital literacy of future teachers [32].

This enables us to summarize some achievements in gamification that are now being used in higher education.

Many social and computer games that are not intended to be strictly educational actually have an educational aspect. Monopoly teaches us basic principles of the market economy, Microsoft's Age of Empires series, Total War, and Civilization teach political economy, history, military theory, and even sociology and ecology.

Many games teach management: Transport Tycoon (managing urban and intercity transport), Railroad Tycoon (managing a railway), Rollercoaster Tycoon (managing an amusement park), Sim City I-IV (managing a modern city), Football Manager (managing a football club), and many others [33, p. 147].

There is another category of games that are created directly by teachers for use in specific academic disciplines. They are distinguished from the previous category by the fact that they have specific educational goals, they were not created for leisure, but designed by teachers of specific academic disciplines; access to them is limited, which is why they are not popular outside academic institutions.

Thus, the experience of gamification in the educational process allows us to summarize achievements and outline prospects for creating educational games in various aspects: from choosing a platform to creating motivating avatars.

The aim of the article is to present the results of testing free tools for creating educational games, and to make a list of characteristics for assessing and identifying the best games for use in higher educational institutions. The testing was part of a pedagogical experiment held at State Higher Educational Institution "Pereiaslav-Khmelnytskyi Hryhorii Skovoroda State Pedagogical University" (Pereiaslav-Khmelnytskyi (Ukraine)), "Kahramanmaras Sutcu Imam" University (Turkey) and "Trakia University" (Bulgaria), whose main goal was for the teachers of humanities to create educational games using free gaming tools.

\section{RESEARCH METHODS}

We approach the research problem by taking a science research approach; first, by summarizing current literature on existing tools for creating educational games, compiling an exhaustive list of indicators for testing selected tools. Second, and more importantly, we collected and analyzed the opinions of teachers who created educational games (but do not have specialized knowledge in the field of programming). Finally, we evaluate the tools for creating educational games by interviewing teachers and students for whom such games were developed.

Teachers of the humanities at Ukrainian universities already have experience in developing immersive applications; however, they had some technical support with codes in Java. Nowadays, not all teachers have access to game development tools, therefore, it is important to help every teacher become aware of the educational game creation process. Kahramanmaras Sutcu Imam University's experience is especially important when it comes to shaping ICT competencies. Based on this experience, we intended to see how the level of ICT competence influences the evaluation of educational games.

Participants were teachers and students from three universities (State Higher Educational Institution "Pereiaslav-Khmelnytskyi Hryhorii Skovoroda State Pedagogical 
University", Pereiaslav-Khmelnytskyi (Ukraine), Kahramanmaras Sutcu Imam University (Turkey) and Trakia University (Bulgaria)). Teachers from Pereiaslav-Khmelnytskyi University taught students majoring in "Commodity" and "Service Sector". In total, 10 teachers and 40 students (undergraduate level) from Ukraine participated in the experiment.

12 teachers and 48 students from the Turkish university majoring in "Economics" and "Public administration" took part in the research.

Trakia University was represented by 10 teachers and 45 students majoring in "Business economics" and "Regional economics".

An important element was the selection of teaching staff for participation in the experiment, which consisted of two stages. The first stage presupposed the selection of teachers of academic disciplines in one area of knowledge (Marketing, Commodity, Economics, Management were selected). The second stage consisted in analyzing the level of teachers' competences in the field of gamification. For this, a questionnaire was developed, which consisted of 20 open-ended questions that required a detailed written answer, for example: "Choose familiar terms and let others define them (HTML5, Android, iOS, Windows, Mac, Linux, Xbox One, Microsoft Store)", "What is the Blueprint system?", "What is the difference between 2D and 3D games?", etc. The survey showed that teachers selected during the first stage had a low level of competences in the field of gamification. Therefore, experiment participants were selected at this stage.

An important aspect for the experiment results was the selection of universities with approximately the same level of achievement in gamification, while also having differences in the educational process and its organization. Thus, gamification appeared in the Ukrainian university only in 2017 (it started with the development of games for "Commodity Research" course). At the time of the experiment, the Turkish university was only starting to implement gamification into its educational process (computer games were developed using AR-objects, which helped students plunge into the professional environment). In addition, the Turkish University organized courses providing advanced training in the field of information technology, which took place in parallel with our experiment. In Trakia University, the department of information technology consisting of programmers and teachers work together to develop educational games that may facilitate gamification. Based on this, we have identified the features of each university to evaluate the efficiency of software tools for game development.

Research. The idea of educational process gamification is not new, but in our experiment, we tried to introduce it to teachers and students in a new way. Namely, games made by non-professionals in the IT field, gamification as part of lifelong vocational training, gamification as a means of establishing contact with students when a teacher is not a specialist in this field and learns along with students.

The research of effective game development software tools consisted of several stages.

1. Preparation (February-March 2018). At this stage, objectives, methodology, principles of the experiment were determined. Teachers identified topics that educational games would be dedicated to, developed game content. An important aspect was the definition of the most popular game development software tools, which were to be used by teachers to develop educational games and by students to form specific competencies. Game development software tools for the experiment were selected based on the analysis of their content popularity. The array of information analyzed included references in the Online gaming forums (NeoGAF, GameFAQs, IGN, The Verge, Student edge, Steam). Teachers also compiled a list of competencies to be formed after using educational games. To this end, each teacher developed a mechanism and criteria for assessing generated competencies. 
2. Experiment implementation (April-June 2018). Teachers developed educational games using the following specific game development software tools: Construct 3, GameMaker Studio 2, Unity, Godot Engine, and Unreal Engine 4.

3 . Testing of the developed educational games by students and exchange of experience with teachers from partner universities using virtual exchange technology and tools to support it (Skype, Zoom, Webex, etc.) (September-October 2018).

4. Analysis of the effectiveness of game development software tools according to the selected criteria. This analysis included two data arrays: the first was the opinion of teachers who developed educational games, and the second - that of students who tested the resulting game product (Appendix Tables 1, 2, 3, 4).

\section{RESULTS AND DISCUSSION}

During the study, we tested free tools for developing educational games, created a list of characteristics for assessing and identifying the ones that are the best for higher educational institutions.

Teachers analyzed cognitive and practical results from the use of developed educational games. This was made possible by assessing formed competencies that were identified for each class and game (each topic/seminar or practical class was accompanied by a new educational game developed using new free tools for creating educational games). Therefore, it became possible to determine the most effective tool for developing students' cognitive abilities. In Ukraine, such tool was GameMaker Studio 2, in Turkey and Bulgaria - the Unreal Engine 4.

Based on the practical conclusions of teachers and students, the following characteristics of each tool may be highlighted.

Unreal Engine 4 has earned the greatest number of points in terms of teachers' trust and effective competence development.

We can identify some features of the experiment winner. Of all the tools on this list, UE4 is the most professional. The unique selling point of UE4 is its Blueprint system, which allows creating game logic without touching any code. The UE4 YouTube channel has over 800 videos that take you through every inch of the engine, and most of those videos are between 20 and 60 minutes long. UE4 allows seamless exporting to multiple platforms: Windows, Mac, Linux, Android, iOS, HTML5, PlayStation 4, Xbox One, Oculus VR, and more.

Construct 3. This game development tool is completely GUI-driven, meaning everything is drag-and-drop. Game logic and variables are implemented using design features provided by the app itself.

GameMaker Studio 2. Like Construct 3, GameMaker Studio 2 allows creating entire games using nothing more than its drag-and-drop interface for variables and game logic. But unlike Construct 3, GameMaker Studio 2 grants more power through its Game Maker Language, which is a C-like scripting language with a lot of flexibility.

Unity. Everything in the game is an object and it is possible to attach various components to each object, where each component controls some aspect of the object's behavior and logic.

Godot Engine. Like Unity, Godot supports the creation of both 2D and 3D games. Godot's approach to game architecture is unique in that everything is divided into scenes. In Godot, a scene is a collection of elements like sprites, sounds, and/or scripts. You can then combine multiple scenes into a bigger scene, and later aggregate these scenes into even bigger ones. This hierarchical design approach makes it very easy to stay organized and modify individual elements whenever you want. Godot uses a drag-and-drop system for maintaining scene elements, but each of these elements can be extended through the built-in scripting system, which uses a custom Python-like language called GDScript. 
When assessing overall tool performance, Ukrainian teachers preferred GameMaker Studio 2. It is a good choice because it supports many interesting quality-of-life features right out of the box, such as the ability to add in-app purchases to the game, real-time analytics on how users play the game, source control, multiplayer networking, and extensibility through third-party extensions. Moreover, it has built-in editors for images, animations, and shades. But unlike Unity, GameMaker Studio 2 does not require any programming skills.

Turkish and Bulgarian teachers preferred the Unreal Engine 4. The reason for this is not that this program is the easiest, but because it features technical support provided by IT professionals. This motivated students and teachers to continue using it.

\section{CONCLUSIONS}

In the course of the experiment, the following free tools for creating educational games were tested: Construct 3, GameMaker Studio 2, Unity, Godot Engine and Unreal Engine 4.

A general score that each tool received consisted of the sum of points given by teachers and students. When assessing these programs, they used certain criteria which helped them determine the best game development tools for them.

Based on these criteria, Ukrainian, Turkish, and Bulgarian teachers, who took part in the experiment, named Unreal Engine 4 as the best tool, while Unity's score was the smallest. Such similar results indicate an almost identical level of digital competencies and issues in the process of software tool testing.

Student testing of developed games consisted in a double survey. The first was based on their preferences (emotional aspect), where they gave an answer to the following statement: "I am pleased with educational games and I want to repeat this experience". Thus, students from Ukraine liked educational games developed using Construct 3 more, while Turkish students and students from Bulgaria preferred those created using Unity.

The next stage presupposed testing of the level of competencies (cognitive aspects) resulting from the use of educational games in the course of learning a new topic. At this stage, students from all three countries showed approximately the same level of competence development after working in the gamified education environment.

Overall results included scores from both teachers and students. Based on them, the most and the least preferred tools were determined. In Ukraine, these were GameMaker Studio 2 and Unity; in Turkey - Unreal Engine and Unity; and in Bulgaria - Unreal Engine 4 and Unity respectively.

The assessment of each software criterion differs from teacher to teacher. However, there are apparent leaders (such as Construct 3, Unreal Engine 4). This is because each of the teachers singled out and assessed the most significant criteria that influenced their selection of software the ability to create games without technical programming skills and export it to any device. These factors were decisive for teachers who took part in the pedagogical experiment.

The results obtained constitute a subjective opinion of specific teachers and students, therefore, they cannot serve as a recommendation to use a certain software tool. The results indicate students' interest in the gamified educational environment. At the same time, the situation with teachers is quite complicated, as they had to develop educational games themselves (with some technical support!). This led to some inaccuracies, the development of educational games lasted a considerable amount of time, as for each of these teachers it was the first attempt at creating a computer educational game. Therefore, in the future, universities that participated in the experiment plan to launch courses aimed at enhancing digital competencies with a focus on the use of gamified elements.

Further research must be targeted at analyzing and testing the efficiency of gamification mechanisms to increase motivation, loyalty, quality of professional education, student 
engagement in the educational process. In addition, it is important to create educational courses, training sessions for the development of digital skills in teachers with a compulsory focus on gamification aspects. Educational goals may be more effectively achieved through the gamified educational environment by using AR/VR objects and 3D visualization.

\section{REFERENCES (TRANSLATED AND TRANSLITERATED)}

[1] J. Majuri, J. Koivisto and J. Hamari, Gamification of education and learning: A review of empirical literature. In Proceedings of the 2nd International GamiFIN Conference, GamiFIN 2018. CEUR-WS. (in English).

[2] L. A. Annetta, M. T. Cheng, and S. Holmes, Assessing twenty first century skills through a teacher created video game for high school biology students. Research in Science \& Technological Education, 2010, 28(2), (in English).

[3] A. Amory, and R. Seagram, Educational game models: conceptualization and evaluation: the practice of higher education. South African Journal of Higher Education, 17(2), 2003, pp. $206-217$ (in English).

[4] A. Round, The Decline in Student Applications to Computer Science and IT Degree Courses in UK Universities. Report on research commissioned by CPIIC, 2006. [Online]. Available: http://www.cra.org/Activities/snowbird/2006/ earnshaw.round.pdf. Accessed on: August, 10, 2009

[5] E. Ye, C. Liu and J. A. Polack-Wahl, Enhancing software engineering education using teaching aids in 3-D online virtual worlds. In 2007 37th Annual Frontiers In Education Conference-Global Engineering: Knowledge Without Borders, Opportunities Without Passports, 2007, October, pp. T1E-8. IEEE. (in English).

[6] J. Kirriemuir, Video gaming, education and digital learning technologies. D-lib Magazine, 2002, 8(2), 7. (in English).

[7] G. Clarke, J. Kehoe and D. O'Broin, The Effects of Gamification on the Formation of a Habit of Studying in Tertiary Level Students. In European Conference on Games Based Learning. 2017, October, pp. 871-880. Academic Conferences International Limited. (in English).

[8] S. Deterding, Gamification. Journal in interactions, 4, pp. 14-15. 2012, doi: 10.1145/2212877.2212883. (in English).

[9] D. Dicheva, C. Dichev, G. Agre and G. Angelova, Gamification in education: A systematic mapping study. Educational Technology \& Society, 2015, 18(3), pp. 75-88. (in English).

[10] C. M. Kanode and H. M. Haddad, Software engineering challenges in game development. In 2009 Sixth International Conference on Information Technology: New Generations, 2009, April, pp. 260-265. IEEE. (in English).

[11] F. Mehm, C. Reuter, S. Göbel and R. Steinmetz, Future trends in game authoring tools. In International Conference on Entertainment Computing , 2012, September, pp. 536-541. Springer, Berlin, Heidelberg. (in English).

[12] A. Rapp, F. Hopfgartner, J. Hamari, C. Linehan and F. Cena, Strengthening gamification studies: Current trends and future opportunities of gamification research. 2018, doi:10.1016/j.ijhcs.2018.11.007. (in English).

[13] D. Liu, R. Santhanam and J.Webster, "Towards meaningful engagement: a framework for design and research of gamified information systems", MIS Quarterly, 2017, Vol. 41 No. 4, pp. 1011-1034. (in English).

[14] H. Warmelink, J. Koivisto, I. Mayer, M. Vesa and J. Hamari, Gamification of the work floor: A literature review of gamifying production and logistics operations, 2018 (in English).

[15] I. Glover, Play as you learn: gamification as a technique for motivating learners, in Proceedings of World Conference on Educational Multimedia, Hypermedia and Telecommunications, AACE, Chesapeake, VA, 2013, pp. 1999-2008 (in English).

[16] J. Hamari, J. Koivisto, H. Sarsa, Does gamification work? - A literature review of empirical studies on gamification, 47th Hawaii International Conference on System Sciences, Hawaii, USA, 2014, January 06-09 (in English).

[17] G. Barata, S. Gama, J. Jorge, D. Gonçalves, Engaging engineering students with gamification, 5th International Conference Games and Virtual Worlds for Serious Applications (VS-GAMES), 2013, September 11-13.

[18] B. Leong, Gamification: How to do it Right and Why it is No Good, Technology in Pedagogy, 2012, No. 13, November (in English).

[19] M. Sillaots, Gamification of Higher Education by the Example of Computer Games Course, The Seventh International Conference on Mobile, Hybrid, and Online Learning - eLmL 2015, Lisbon, Portugal, February 22-27, 2015, [Online]. Available:http://www.thinkmind.org/index.php?view= article\&articleid=elml_2015_4_20_50048. Accessed on: July 08, 2015 (in English).

[20] S. Smith-Robbins, This Game Sucks: How to Improve the Gamification of Education, Educause Review, 46 (1), 2011, pp.58-59, [Online]. Available: http://net.educause.edu/ir/library/pdf/ERM1117.pdf. Accessed on: July 05, 2015 (in English).

[21] B. Kim, H. Park, Y. Baek, Not just fun, but serious strategies: Using meta-cognitive strategies in gamebased learning, Computers \& Education, 52(4), 2009, pp. 800-810 (in English). 
[22] A. Domínguez, J. Saenz-de-Navarrete, L. de-Marcos, L. Fernández-Sanz, C. Pagés, J. Martínez-Herráiz, Gamifying learning experiences: Practical implications and outcomes, Computers \& Education 63, 2013, pp 380-392 (in English).

[23] D. Codish, G. Ravid, Personality Based Gamification - Educational Gamification for Extroverts and Introverts, In Proceedings of the 9th CHAIS Conference for the Study of Innovation and Learning Technologies: Learning in the Technological Era, 2014, pp. 36-44 (in English).

[24] P. Denny, The Effect of Virtual Achievements on Student Engagement, CHI 2013: Changing Perspectives, Paris, France, 2013, pp. 5-8 (in English).

[25] Wiggins, E. Bradley, An overview and study on the use of games, simulations, and gamification in higher education. International Journal of Game-Based Learning (IJGBL) 6.1, 2016: pp.18-29. (in English).

[26] M. Laskowski, M. Badurowicz, Gamification in higher education: a case study. Make Learn International Conference. Vol. 25. 2014. (in English).

[27] S. Šćepanović, N. A Žarić, T. Matijević, Gamification in higher education learning-state of the art, challenges and opportunities. The Sixth International Conference on e-Learning (eLearning-2015), 24-25 September 2015, Belgrade, Serbia. 2015. (in English).

[28] A. Yurzhenko, S. Voloshinov, G. Popova, Using a Gamified Approach to Create an EMS Course in LMS MOODLE in Dual Education, 2019 (in Ukrainian).

[29] O. V. Povstin, Innovative teaching methods in higher education institutions: examples of gamification. Competitiveness of Higher Education of Ukraine in the Information Society: Collection of Abstracts of the II International Scientific and Practical Conference, Chernihiv, October 11, 2019. Chernihiv. nat. technol. Univ. of Chernihiv, 293 p. (in Ukrainian).

[30] T. Leshchenko, M. Grishunina, V. Pichkur, Gamification as one of the innovative forms of the educational process. 2018. [Online]. Available: http://repositary.knuba.edu.ua/handle/987654321/1553 (in Ukrainian).

[31] N. Rybka, Grief and experience in the use of computer games in philosophy education in technical higher education institutions. Information Technologies and Learning Tools, 2018, Volume 67, No.5. doi: https://doi.org/10.33407/itlt.v67i5.2108. (in Ukrainian).

[32] O. A. Zhernovnykova, L. Peretiaha, A. Kovtun, M. Korduban, O. Nalyvaiko, N. Nalyvaiko, The technology of prospective teachers' digital competence formation by means of gamification. Information Technologies and Learning tools, 2020, Volume 75, No.1. [Online]. Available: https://journal.iitta.gov.ua/index.php/itlt/article/view/3036 (in English).

[33] M. Minović, M. Milovanović, and D. Starcevic, Literature review in game-based learning. In World Summit on Knowledge Society. September 2011, pp. 146-154. Springer, Berlin, Heidelberg. (in English).

Text of the article was accepted by Editorial Team 06.09.2019

\title{
ПРОГРАМНІ ІНСТРУМЕНТИ ДЛЯ ГЕЙМІФІКАЦІЇ У ВИЩИХ НАВЧАЛЬНИХ ЗАКЛАДАХ: ДОСВІД УКРАЇНИ, ТУРЕЧЧИНИ ТА БОЛГАРІЇ
}

\author{
Доброскок Ірина \\ член-кореспондент Національної академії педагогічних наук України,доктор педагогічних наук, \\ професорка \\ ДВНЗ «Переяслав-Хмельницький державний педагогічний університет імені Григорія Сковороди», \\ м. Переяслав-Хмельницький, Україна \\ ORCID 0000-0002-3937-8428 \\ irina.dobroskok@gmail.com \\ Ржевська Наталія \\ кандидат педагогічних наук \\ ДВНЗ «Переяслав-Хмельницький державний педагогічний університет імені Григорія Сковороди», \\ м. Переяслав-Хмельницький, Україна \\ ORCID 0000-0001-8695-5964 \\ zolotysya@ukr.net
}

\section{Айїлдиз Хамді}

кандидат економічних наук, Центр розвитку та координації проєктів Туркоглу

Університет Суджу Імама в Кахраманмараші, Туреччина

ORCID 0000-0001-6280-7182

hayyildiz@ksu.edu.tr 


\author{
Заімова Дарина \\ доцент, проректор з міжнародної проєктної роботи \\ Університет Тракіа, Болгарія \\ ORCID 0000-0001-6971-3701 \\ dzaimova@gmail.com
}

Желязков Георгій

кандидат наук, професор, завідувач кафедри підприємництва та промислового бізнесу

Університет Тракіа, Болгарія

ORCID 0000-0002-2575-6977

george-zh@mbox.digsys.bg

\begin{abstract}
Анотація. Стаття присвячена аналізу програмних засобів для розробки навчальних ігор у вищих навчальних закладах України (Переяслав-Хмельницький державний педагогічний університет імені Григорія Сковороди), Туреччини (Університет імені Кахраманмараса) та Болгарії (Університет Тракіа). Сьогодні ці технології активно впроваджуються в різних сферах діяльності: від медицини до банківської справи, від спортивних до військових тренувань. У статті висвітлюються результати науково-педагогічної та дослідницької роботи викладачів та студентів університетів, що полягала у створенні навчальних ігор викладачами, які не мають такого досвіду та спеціалізованих IT-навичок. Для проведення дослідження були обрані безкоштовні програмні засоби, які можна використовувати для створення навчальних ігор. За результатами дослідження варто відзначити високий інтерес як викладачів, так і учнів до створення та використання комп'ютерних навчальних ігор. Отже, викладачі матимуть найкращі практики використання інформаційних технологій, що дозволить їм реалізувати свої інноваційні ідеї та встановити тісні стосунки $з$ провідними зацікавленими сторонами у формуванні сучасних компетентностей майбутніх фахівців. Основним завданням використання технології доповненої реальності та гейміфікації навчання є підтримка вивчення обраної предметної галузі, використання AR-об'єктів, анімованих об'єктів, інтерактивних завдань тощо. Вони спрямовані на підвищення якості та змісту освіти шляхом забезпечення рівного доступу студентів до освітніх послуг незалежно від місця знаходження, їх соціального стану та стану здоров'я. Це дає можливість кожному викладачу зробити навчання цікавим та підвищити мотивацію і розширити коло слухачів. Слід зазначити, що ці результати є актуальними лише для конкретних досліджуваних груп, оскільки грунтуються на індивідуальному досвіді конкретно обраних викладачів та студентів. Але вони дуже важливі для формування уявлень про педагогічні стратегії і дають викладачам можливість дізнатися аспекти роботи 3 новою інформацією, новим типом роботи, новими засобами взаємодії.
\end{abstract}

Ключові слова: Construct 3; навчальна гра; GameMaker Studio 2; гейміфікація; вищі навчальні заклади; Godot Engine; Unity; Unreal Engine 4.

\title{
ПРОГРАММНЫЕ ИНСТРУМЕНТЫ ДЛЯ ГЕЙМИФИКАЦИИ В ВЫСШИХ УЧЕБНЫХ ЗАВЕДЕНИЯХ: ОПЫТ УКРАИНЫ, ТУРЦИИ И БОЛГАРИИ
}

\author{
Доброскок Ирина \\ член-корреспондент Национальной академии педагогических наук Украины, доктор педагогических \\ наук, профессор \\ ГВУЗ «Переяслав-Хмельницкий государственный педагогический университет имени Григория \\ Сковороды», г. Переяслав-Хмельницкий, Украина \\ ORCID 0000-0002-3937-8428 \\ irina.dobroskok@gmail.com

\section{Ржевская Наталья} \\ кандидат педагогических наук \\ ГВУЗ «Переяслав-Хмельницкий государственный педагогический университет имени Григория \\ Сковороды», г. Переяслав-Хмельницкий, Украина \\ ORCID 0000-0001-8695-5964 \\ zolotysya@ukr.net
}




\author{
Айилдиз Хамди \\ Университет Суджу Имама в Кахраманмараше, Турция \\ ORCID 0000-0001-6280-7182 \\ hayyildiz@ksu.edu.tr

\section{Заимова Дарья} \\ доцент, проректор по международной проектной работе \\ Университет Тракии, Болгария \\ ORCID 0000-0001-6971-3701 \\ dzaimova@gmail.com
}

кандидат экономических наук, Центр развития и координации проектов Туркоглу

\title{
Желязков Георгий
}

кандидат наук, профессор, заведующий кафедрой предпринимательства и промышленного бизнеса Университет Тракии, Болгария

ORCID 0000-0002-2575-6977

george-zh@mbox.digsys.bg

Аннотация. Статья посвящена анализу программных средств для разработки обучающих игр в высших учебных заведениях Украины (Переяслав-Хмельницкий государственный педагогический университет имени Григория Сковороды), Турции (Университет имени Кахраманмараса) и Болгарии (Университет Тракии). Сегодня эти технологии активно внедряются в различных сферах деятельности: от медицины до банковского дела, от продаж промышленных гигантов до спортивных и военных тренировок. В статье освещаются результаты научно-педагогической и исследовательской работы преподавателей и студентов указанных университетов, которая заключалась в создании обучающих игр преподавателями, которые не имеют такого опыта и специализированных ИТ-навыков. Для проведения исследования были выбраны бесплатные программные инструменты, которые можно использовать для создания обучающих игр. По результатам исследования следует отметить высокий интерес как преподавателей, так и студентов к созданию и использованию компьютерных обучающих игр. Итак, преподаватели будут иметь лучшие практики использования информационных технологий, что позволит им реализовать свои инновационные идеи и установить тесные отношения с ведущими заинтересованными сторонами в формировании современных компетентностей будущих специалистов. Основной задачей использования технологии дополненной реальности и геймификации обучения является поддержка изучения выбранной предметной области, использование ARобъектов, анимированных объектов, интерактивных задач и тому подобное. Они направлены на повышение качества и содержания образования путем обеспечения равного доступа студентов к образовательным услугам независимо от места нахождения, их социального положения и состояния здоровья. Это дает возможность каждому преподавателю сделать обучение интересным, повысить мотивацию и привлечение слушателей. Следует отметить, что эти результаты актуальны только для конкретных исследуемых групп, поскольку основываются на индивидуальном опыте выбранных преподавателей и студентов. Но они очень важны для формирования представлений о педагогических стратегиях и дают преподавателям возможность узнать аспекты работы с новой информацией, новым типом работы, новыми средствами взаимодействия.

Ключевые слова: Construct 3; обучающая игра; GameMaker Studio 2; геймификация; высшие учебные заведения; Godot Engine; Unity; Unreal Engine 4. 


\section{APPENDIX}

Table 1

Diagnostics of the effectiveness of game development software tools according to the selected criteria

\begin{tabular}{|c|c|c|c|c|c|c|c|c|c|c|c|c|c|c|c|c|c|c|c|c|c|}
\hline \multirow[t]{2}{*}{$\begin{array}{c}\text { Game } \\
\text { development } \\
\text { software tools }\end{array}$} & \multicolumn{3}{|c|}{$\begin{array}{l}\text { No programming } \\
\text { needed. } \\
\text { It is the best option if } \\
\text { you've never written } \\
\text { a line of code in your } \\
\text { life. Everything is } \\
\text { drag-and-drop } \\
\text { Blueprint system, } \\
\text { which lets you create } \\
\text { game logic without } \\
\text { touching any code }\end{array}$} & \multicolumn{3}{|c|}{$\begin{array}{c}\text { It can export to } \\
\text { dozens of different } \\
\text { platforms and } \\
\text { formats, and you } \\
\text { don't have to change } \\
\text { a single thing in your } \\
\text { game to } \\
\text { accommodate these } \\
\text { various options. Once } \\
\text { your game is done, } \\
\text { you can export to } \\
\text { HTML5, Android, } \\
\text { iOS, Windows, Mac, } \\
\text { Linux, Xbox One, } \\
\text { Microsoft Store, and } \\
\text { more. }\end{array}$} & \multicolumn{3}{|c|}{$\begin{array}{l}\text { There are hundreds of } \\
\text { tutorials that will help } \\
\text { you understand } \\
\text { concepts from basic } \\
\text { to advanced, and the } \\
\text { forum community is } \\
\text { extremely active if } \\
\text { you ever need } \\
\text { assistance }\end{array}$} & \multicolumn{3}{|c|}{$\begin{array}{l}\text { The ability to add in- } \\
\text { app purchases to your } \\
\text { game, real-time } \\
\text { analytics on how } \\
\text { users play your game, } \\
\text { source control, } \\
\text { multiplayer } \\
\text { networking, and } \\
\text { extensibility through } \\
\text { third-party extensions }\end{array}$} & \multicolumn{3}{|c|}{$\begin{array}{l}\text { Everything in the } \\
\text { game is an object and } \\
\text { you can attach } \\
\text { various components } \\
\text { to each object, where } \\
\text { each component } \\
\text { controls some aspect } \\
\text { of the object's } \\
\text { behavior and logic }\end{array}$} & \multicolumn{3}{|c|}{$\begin{array}{c}\text { Supports the } \\
\text { creation of both 2D } \\
\text { and 3D games }\end{array}$} & \multicolumn{3}{|c|}{$\begin{array}{l}\text { Driving principles } \\
\text { allow you to iterate } \\
\text { and develop as } \\
\text { quickly as you can, so } \\
\text { you get features like } \\
\text { live debugging, hot } \\
\text { reloading, a } \\
\text { streamlined asset } \\
\text { pipeline, instant game } \\
\text { previews, plus } \\
\text { hundreds of included } \\
\text { assets and systems } \\
\text { like artificial } \\
\text { intelligence, } \\
\text { cinematic tools, post- } \\
\text { processing effects, } \\
\text { and more }\end{array}$} \\
\hline & $\mathbf{U}^{1}$ & $\mathbf{T}^{2}$ & $\mathbf{B G}^{3}$ & $\mathbf{U}$ & $\mathbf{T}$ & BG & $\mathbf{U}$ & $\mathbf{T}$ & BG & $\mathbf{U}$ & $\mathbf{T}$ & BG & $\mathbf{U}$ & $\mathbf{T}$ & BG & $\mathbf{U}$ & $\mathbf{T}$ & BG & $\mathbf{U}$ & $\mathbf{T}$ & BG \\
\hline Construct 3 & 61.73 & 45.86 & 41.59 & 3.54 & 22.51 & 19.78 & 15.78 & 7.65 & 5.45 & 2.87 & 5.87 & 10.45 & 8.78 & 1.21 & 12.42 & 2.85 & 9.12 & 5.86 & 4.45 & 7.78 & 4.45 \\
\hline Unity & 0 & 0 & 0 & 15.87 & 10.15 & 11.54 & 10.87 & 14.78 & 17.20 & 10.32 & 15.87 & 17.87 & 22.16 & 33.12 & 16.11 & 39.17 & 5.94 & 18.13 & 1.61 & 20.14 & 19.15 \\
\hline Godot Engine & 18.96 & 15.45 & 29.69 & 5.78 & 8.75 & 6.36 & 9.60 & 31.76 & 27.26 & 15.98 & 16.12 & 6.71 & 3.45 & 4.32 & 4.45 & 17.12 & 4.45 & 5.36 & 29.11 & 19.15 & 20.17 \\
\hline Unreal Engine 4 & 50.42 & 31.66 & 20.19 & 0.87 & 35.68 & 25.78 & 19.97 & 5.74 & 34.82 & 0.45 & 8.98 & 8.79 & 9.87 & 1.36 & 4.12 & 8.42 & 8.13 & 3.32 & 10.00 & 8.45 & 2.98 \\
\hline \multicolumn{22}{|c|}{ GENERAL SCORE } \\
\hline Construct 3 & 2.87 & 5.64 & 9.17 & \multirow{5}{*}{\multicolumn{18}{|c|}{ Calculated as an arithmetic average in the opinion of teachers }} \\
\hline $\begin{array}{l}\text { GameMaker } \\
\text { Studio } 2\end{array}$ & 4.16 & 28.14 & 36.12 & & & & & & & & & & & & & & & & & & \\
\hline Unity & 2.10 & 0.12 & 1.65 & & & & & & & & & & & & & & & & & & \\
\hline Godot Engine & 36.18 & 44.17 & 37.87 & & & & & & & & & & & & & & & & & & \\
\hline Unreal Engine 4 & 45.23 & 54.23 & 41.83 & & & & & & & & & & & & & & & & & & \\
\hline
\end{tabular}

\footnotetext{
${ }^{1}$ Ukraine

${ }^{2}$ Turkey

${ }^{3}$ Bulgaria
} 
Table 2

\section{Students' perceptions of educational games}

\begin{tabular}{|c|c|c|c|c|c|c|}
\hline Statement & \multicolumn{6}{|c|}{ Evaluation } \\
\hline $\begin{array}{l}\text { I am pleased with the } \\
\text { educational games and I } \\
\text { want to repeat this } \\
\text { experience }\end{array}$ & $\begin{array}{c}\text { Strongly } \\
\text { agree } \\
\text { (SA) }\end{array}$ & Agree (A) & $\begin{array}{c}\text { Neither } \\
\text { agree nor } \\
\text { disagree }\end{array}$ & $\begin{array}{l}\text { Disagree } \\
\text { (D) }\end{array}$ & $\begin{array}{c}\text { Strongly } \\
\text { disagree } \\
\text { (SA) }\end{array}$ & $\begin{array}{l}\text { Don't } \\
\text { know }\end{array}$ \\
\hline \multicolumn{7}{|c|}{ Ukraine } \\
\hline Construct 3 & 96.77 & 2.87 & 0.36 & 0 & 0 & 0 \\
\hline GameMaker Studio 2 & 90.61 & 8.56 & 1.77 & 0 & 0 & 0 \\
\hline Unity & 87.32 & 11.22 & 2.03 & 0 & 0 & 1.29 \\
\hline Godot Engine & 51.40 & 33.42 & 12.25 & 0 & 0 & 2.93 \\
\hline Unreal Engine 4 & 44.21 & 28.70 & 15.87 & 0 & 0 & 11.22 \\
\hline \multicolumn{7}{|c|}{ Turkey } \\
\hline Construct 3 & 90.61 & 8.56 & 1.77 & 0 & 0 & 0 \\
\hline GameMaker Studio 2 & 94.19 & 3.25 & 2.56 & 0 & 0 & 0 \\
\hline Unity & 98.30 & 1.20 & 0.50 & 0 & 0 & 0 \\
\hline Godot Engine & 61.15 & 23.25 & 15.6 & 0 & 0 & 0 \\
\hline Unreal Engine 4 & 68.30 & 30.00 & 0.50 & 0 & 0 & 1.20 \\
\hline \multicolumn{7}{|c|}{ Bulgaria } \\
\hline Construct 3 & 87.32 & 11.22 & 2.03 & 0 & 0 & 1.29 \\
\hline GameMaker Studio 2 & 38.70 & 38.56 & 12.29 & 0 & 0 & 10.45 \\
\hline Unity & 96.06 & 3.44 & 0.50 & 0 & 0 & 0 \\
\hline Godot Engine & 55.34 & 44.16 & 0.50 & 0 & 0 & 0 \\
\hline Unreal Engine 4 & 77.30 & 21.24 & 2.03 & 0 & 0 & 1.29 \\
\hline
\end{tabular}

Table 3

\section{Competency assessment}

\begin{tabular}{|c|c|c|c|}
\hline Game & $\begin{array}{c}\text { Low level } \\
(\mathbf{\%})\end{array}$ & $\begin{array}{c}\text { Average } \\
\text { level (\%) }\end{array}$ & $\begin{array}{c}\text { High level } \\
(\%)\end{array}$ \\
\hline \multicolumn{3}{|c|}{ Ukraine } \\
\hline Construct 3 & 0.61 & 98.56 & 1.77 \\
\hline GameMaker Studio 2 & 1.15 & 23.25 & 75.6 \\
\hline Unity & 6.77 & 92.87 & 0.36 \\
\hline Godot Engine & 6.06 & 93.44 & 0.50 \\
\hline Unreal Engine 4 & 5.34 & 44.16 & 50.50 \\
\hline \multicolumn{3}{|c|}{ Turkey } \\
\hline Construct 3 & 4.19 & 93.25 & 2.56 \\
\hline GameMaker Studio 2 & 8.30 & 91.20 & 0.50 \\
\hline Unity & 46.77 & 52.87 & 0.36 \\
\hline Godot Engine & 8.30 & 61.20 & 30.50 \\
\hline Unreal Engine 4 & 6.06 & 53.44 & 40.50 \\
\hline Construct 3 & 6.06 & 53.44 & 40.50 \\
\hline GameMaker Studio 2 & 1.15 & 43.25 & 55.6 \\
\hline Unity & 64.19 & 33.25 & 2.56 \\
\hline Godot Engine & 5.34 & 54.16 & 40.50 \\
\hline Unreal Engine 4 & 8.30 & 1.20 & 90.50 \\
\hline
\end{tabular}


General performance table

\begin{tabular}{|c|c|c|c|c|c|c|c|c|c|c|c|c|}
\hline $\begin{array}{c}\text { Game } \\
\text { development } \\
\text { software } \\
\text { tools }\end{array}$ & \multicolumn{2}{|c|}{$\begin{array}{c}\text { Evaluation by } \\
\text { teachers } \\
\text { (total score is } \\
\text { calculated as an } \\
\text { arithmetic average) }\end{array}$} & \multicolumn{2}{|c|}{$\begin{array}{c}\text { Student Evaluation of } \\
\text { Educational Games } \\
\text { (dominant results of } \\
\text { students with the } \\
\text { opinion of "Strongly } \\
\text { agree") }\end{array}$} & $\begin{array}{c}\text { Evaluation of the } \\
\text { competencies shaping } \\
\text { (a tool that } \\
\text { contributed to the } \\
\text { formation of a high } \\
\text { level of competence) }\end{array}$ & \multicolumn{3}{|c|}{ Total score } \\
\hline & $\mathbf{U}$ & $\mathbf{T}$ & $\mathbf{B G}$ & $\mathbf{U}$ & $\mathbf{T}$ & $\mathbf{B G}$ & $\mathbf{U}$ & $\mathbf{T}$ & $\mathbf{B G}$ & $\mathbf{U}$ & $\mathbf{T}$ & BG \\
\hline Construct 3 & 2.87 & 5.64 & 9.17 & 96.77 & 90.61 & 87.32 & 1.77 & 2.56 & 40.50 & 101.44 & 98.81 & 136.99 \\
\hline $\begin{array}{c}\text { GameMaker } \\
\text { Studio 2 }\end{array}$ & 4.16 & 28.14 & 36.12 & 90.61 & 94.19 & 38.70 & 75.6 & 0.50 & 55.60 & 170.37 & 122.83 & 130.42 \\
\hline Unity & 2.10 & 0.12 & 1.65 & 87.32 & 98.30 & 96.06 & 0.36 & 0.36 & 2.56 & 89.78 & 98.78 & 100.27 \\
\hline $\begin{array}{c}\text { Godot } \\
\text { Engine }\end{array}$ & 45.23 & 54.23 & 41.83 & 51.40 & 61.15 & 55.34 & 0.50 & 30.50 & 40.50 & 97.13 & 145.88 & 137.67 \\
\hline $\begin{array}{c}\text { Unreal } \\
\text { Engine 4 }\end{array}$ & 36.18 & 44.17 & 37.87 & 44.21 & 68.30 & 77.30 & 50.50 & 40.50 & 90.50 & 130.89 & 152.97 & 205.67 \\
\hline
\end{tabular}

\section{(c) BY-NC-SA}

This work is licensed under Creative Commons Attribution-NonCommercial-ShareAlike 4.0 International License. 